\title{
Poszerzenie puli genetycznej jęczmienia
}

\author{
Broadening of barley gene pool
}

\author{
Urszula Piechota ${ }^{\boxplus}$, Paweł Czembor, Jerzy H. Czembor
}

Instytut Hodowli i Aklimatyzacji Roślin — Państwowy Instytut Badawczy, Radzików, 05-870 Błonie
$\square$ e-mail:u.piechota@ihar.edu.pl

\begin{abstract}
Przedstawiono badania nad określenie uwarunkowania genetycznego odporności na mączniaka prawdziwego czterech linii jęczmienia jarego. Badane linie wykazały odmienny profil reakcji na zastosowane izolaty, co wskazuje na obecność nowych nieznanych genów odporności. Wykazano że lokalne odmiany jęczmienia są potencjalnym źródłem efektywnej odporności.
\end{abstract}

Słowa kluczowe: jęczmień, pula genowa, mączniak prawdziwy

Research to determine the genetic determinant of mildew resistance to four spring barley lines has been presented. The examined lines showed a different reaction profile for the isolates used, which indicates the presence of new unknown resistance genes. It has been shown that local varieties of barley are a potential source of effective immunity.

Key words: barley, gene pool, powdery mildew

Choroby zbóż powodowane przez patogeny grzybowe są ważnem problemem ekonomicznym. Mączniak prawdziwy jęczmienia, wywoływany przez obligatoryjnego biotroficznego patogena grzybowego Blumeria graminis $\mathrm{f}$. sp. hordei, powoduje straty $\mathrm{w}$ plonie oraz obniżenie jakości browarnej ziarna. Pojawianie się i rozprzestrzenianie nowych patotypów prowadzi do znacznego porażenia i epifitoz. Problemem jest wąska pula genetyczna współczesnych elitarnych odmian jęczmienia (Hordeum vulgare L.) uprawianych w Europie. Znanych i zmapowanych na genomie jęczmienia jest 11 genów odporności na mączniaka (Jørgensen i Wolfe, 1994; Schönfeld i in., 1996). Niemal wszystkie, z wyjątkiem recesywnego allelu mlo, niosą odporność rasowo specyficzną. Taki typ odporności jest nietrwały i przełamywany wraz $\mathrm{z}$ pojawieniem się wirulentnych patotypów grzyba. Wcześniejsze doniesienia wykazały, że odmiany miejscowe jęczmienia mogą być źródłem efektywnej odporności na mączniaka prawdziwego (Czembor 2000, 2002; Comadran i in., 2009). Odmiany lokalne wywodzą się z upraw opartych na dynamicznych populacjach, koewoluowały z patogenem i ulegały naturalnej selekcji. Dzięki tym procesom stanowią bogate źródło pożądanej zmienności.

Celem badań jest określenie uwarunkowania genetycznego odporności na mączniaka prawdziwego czterech linii jęczmienia jarego, Bgh255-3-3, Bgh569-3-3, Bgh5317-1-1 i Bgh39408-3-5, wyselekcjonowanych z ponad tysiąca populacji miejscowych pochodzących z rejonów basenu Morza Śródziemnego o tradycyjnej kulturze rolnej. Badania prowa- dzone są $\mathrm{z}$ wykorzstaniem metod genetyki klasycznej, technik biologii molekularnej oraz testów fitopatologicznych.

$\mathrm{Na}$ potrzeby doświadczeń wytworzono populację mapującą krzyżując badane linie odporne z odmianą podatną Manchuria. Analiza dziedziczenia cechy odporności $\mathrm{w}$ populacjach mieszńcowych F2 i rodzinach F3 wykazała, że odporność wszystkich czterech linii jest warunkowana pojedynczym genem dominującym. Badane linie były inokulowane zestawem patotypów różnicujących grzyba. Porównano profile reakcji badanych linii z odpowiedzią 25 blisko izogenicznych linii Pallas, niosących znane geny odporności na mączniaka prawdziwego (Kølster i in., 1986). Badane linie wykazały odmienny profil reakcji na zastosowane izolaty, co wskazuje na obecność nowych nieznanych genów odporności. Analiza molekularna populacji F2 Bgh255-3-3 $\times$ Manchuria została przeprowadzona $\mathrm{z}$ użyciem markerów molekulanych SSR oraz SNP (DarTSeq, CAPS, ASPCR). Analiza wariantów markerów wykazała sprzężenie locus odporności linii Bgh255-3-3 z markerami zlokalizowanymi na chromosomie 2HS. Wyniki zostały użyte do konstrukcji mapy genetycznej zawierającej gen odporności.

Otrzymane wyniki potwierdzają, że lokalne odmiany jęczmienia są potencjalnym źródłem efektywnej odporności. Badane linie jęczmienia Bgh255-3-3, Bgh569-3-3, Bgh5317-1-1 i Bgh39408-3-5 wykazaly szerokie spektrum odporności, reakcję niekompatybilną w układach ze wszystkimi zastosowanymi izolatami Blumeria graminis f. sp. hordei. 
Zaprezentowane wyniki stanowią podsumowanie prac wykonanych $\mathrm{w}$ pierwszym etapie (2015-2017) Programu Wieloletniego „Tworzenie naukowych podstaw postępu biologicznego i ochrona roślinnych zasobów genowych źródłem innowacjii wsparcia zrównoważonego rolnictwa oraz bezpieczeństwa żywnościowego kraju", Zadanie 2.2 (3-2-00-0-02) "Poszerzenie puli genetycznej jęczmienia".

\section{Literatura}

Comadran J., Thomas W. T. B., van Eeuwijk F. Á., Ceccarelli S., Grando S., Stanca A. M., Pecchioni N., Akar T., Al-Yassin A., Benbelkacem A., Ouabbou H., Bort J., Romagosa I., Hackett C. A., Russel J. R. 2009. Patterns of genetic diversity and linkage-disequilibrium in a high structured Hordeum vulgare associationmapping population for the Mediterranean basin. Theor. Appl. Genet.119: 175 — 187.
Czembor J. H. 2000. Resistance to powdery mildew in barley landraces from Morocco. Journal of Plant Pathology 82 (3): $187-200$.

Czembor J. H. 2002. Resistance to powdery mildew in selections from Moroccan barley landraces. Euphytica 125: $397-409$.

Jørgensen J. H., Wolfe M. 1994. Genetics of powdery mildew resistance in barley. Critical Reviews in Plant Science 13 (1): $97-119$.

Kølster P., Munk L., Stølen O., Løhde J. 1986. Nearisogenic barley lines with genes for resistance to powdery mildew. Crop Sci. 26: 903 - 907.

Schönfeld M., Ragni A., Fishbeck G., Jahoor A. 1996. RFLP mapping of three new loci for resistance genes to powdery mildew (Erysiphe graminis f. sp. hordei) in barley. Theor. Appl.Genet. 93: $48-56$.

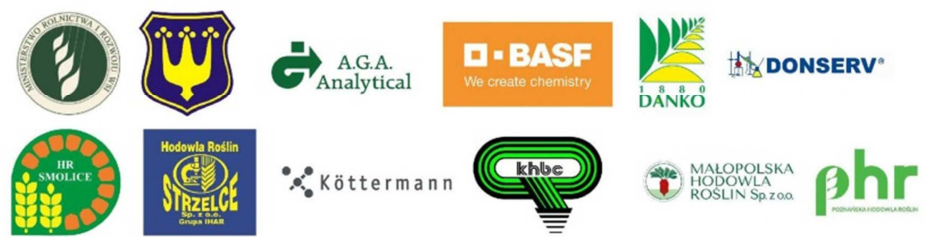

